\title{
DICTATION AS A MEANS OF INTENSIFICATION OF STUDENTS' COGNITIVE AND LEARNING ACTIVITY IN GERMAN CLASS
}

\section{Nadolska Yuliya ${ }^{1}$ \\ Fesenko Ievgeniia ${ }^{2}$}

DOI: https://doi.org/10.30525/978-9934-571-89-3_3

One of the leading areas of student competence is the development of written literacy. The student has to be good and sound at speaking, but also he has to use the learned rules in writing. That is why the effectiveness of the teacher's work is impossible without increasing the efficiency of each class, improving and creative

\footnotetext{
${ }^{1}$ Bogdan Khmelnytsky Melitopol State Pedagogical University, Ukraine

${ }^{2}$ Bogdan Khmelnytsky Melitopol State Pedagogical University, Ukraine
} 
use of methods and forms of teaching a foreign language, among which the dictation plays an important role. The problem under study is justified by these facts.

Today mastering foreign languages aims at acquiring knowledge, skills and abilities that allow foreign language activities to take place and include acquiring such types of speech activity as listening, reading, writing and speaking the language of study. A foreign language, as well as a native one, does not exist in isolation. By performing two important functions - communication and cognition, it serves as a means of not only interpersonal, but also interethnic, interstate, international communication. After graduation, students must not only speak a foreign language, but also be able to correctly read authentic literature, express their thoughts in writing, compose secondary texts (annotations, summaries), that is to possess all kinds of language activities. Therefore, attention should be paid to the level of development of the communicative competence of students in the system of written speech, which should be characterized by a high degree of independence and activity.

Dictation is a method of organization of educational activities of students in the classroom, when students reproduce in writing the text, dictated by parts. It is one of the most effective forms of work that not only helps to control and test the level of knowledge, skills and abilities acquisition, but also contributes to the formation and improvement of spelling skills of a foreign language, as well as the improvement of knowledge on phonetics, vocabulary and grammar.

Dictations, as a form of educational work, are of different types (textual, selective, free and creative), each of which has its own peculiarities [1, p. 4]. Among them we distinguish both traditional and non-traditional ones.

The purpose of our study is the use of non-traditional dictations in German class as an effective means of communicative and spelling skills.

Non-traditional dictations that we use in class include free dictation, creative dictation, picture dictation, walking dictation, spelling-phonetic dictation, whistle dictation, distributive dictation, selective dictation, grammar dictation (dictogram), dictation-dialogue, associative dictation.

In our scientific research, we will outline the creative and research potential of non-traditional dictations and consider some types of dictation examples.

For the development of dialogical speech on the subject "Die Bekanntschaft" students are offered dictation-dialogue in the form of separate, randomly-located replicas, which students must firstly write down, then arrange the question-answer correctly, and then reproduce the text in writing, working in pairs.

Example:

- Guten Tag, ich heiße Tom. Und wie heißt du?

- Woher, Comm du, Lola?

- Ja, und ich arbeite auch hier.

- Hallo, ich bin Lola, Lola Holz.

- Ich komme aus Oldenburg, aber ich wohne jetzt in Berlin.

- Ich studiere hier Musik. Ich will Musizieren werden. Und woher kommst du?

- Wohnst du auch hier?

- Was machst du in Berlin? 
- Ich komme aus Leipzig.

We can offer picture dictations, the purpose of which is to improve language knowledge in a relaxed way. When studying the grammatical theme "Präpositionen mit Dativ und Akkusativ" students have to draw a picture on the basis of the dictated text and then describe the pictures. It enables to improve lexical competence, to check the spelling and to develop speech skills.

Example:

Auf diesem Bild sieht man im Vordergrund einen See. Auf dem See ist ein kleines Boot. Im Boot sitzen ein Mann und ein Kind. Um den See herum geht eine Familie mit einem Hund spazieren. Neben dem See liegt ein Dorf.

In der Mitte des Dorfes gibt es eine Kirche. Links von der Kirche steht das Rathaus. Hinter dem Rathaus ist ein Restaurant. Innerhalb des Dorfes gibt es einen Fußballplatz. Um den See herum gibt es eine kleine Straße. Auf dieser Straße gibt es einen Unfall: ein Fahrradfahrer ist in einen Baum gefahren. Rechts neben dem Dorf ist ein kleiner Berg. Am Berg steht eine alte Burg.

When writing a spelling-phonetic dictation in practical lessons in German as a second foreign language at the initial level of education, the formation of phonetic competence of students takes place. Work on the pronunciation begins from the first day and lasts throughout the period of learning the study material. There is a reorganization of articulation, phonemic hearing, as well as mastering the technique of pronunciation of foreign speech sounds, phrases, sentences in the process of speaking and reading. The role of sound components is very important in written speech. Phonetic dictations develop and exacerbate students' hearing. When writing dictations of the language sound composition, it is advisable to use unfamiliar words, tongue twisters, poems, separate texts, etc. The teacher dictates words that are close by sound, and the students write them down.

For example: Hof-Huf, Ohren-Uhren, lieben-leben, müde-Möbel, böse-büßen.

When studying the German letter I in the practical lesson, which has a short sound [i] and a long sound [i:], and is expressed in writing by the following letters: i, ie, ich, ieh, students are offered to write a text on this topic and pay attention to the sound and spelling of words and find the words with a long sound [i:].

"Ich liebe Dich", schrieb Siegfried seiner Freundin Brigitte. Sie wohnt im Kiel, er in Wien. Viele Kilometer liegen zwischen ihnen.

"Ich will ihn wiedersehen", rief Brigitte, und schnell wie der Wind lief sie mit dem Brief hinaus.

Ein Taxi bringt sie zum Bahnhof. Im Intercity nach Wien findet sie vier Pfennige. Die will sie Siegfried mitbringen als Zeichnen ihrer Liebe. "Ich liebe Dich, Siegfried" [2, p. 40].

Dictation is one of the means of improving the culture of the written language of students. If we use different types of dictations skillfully, depending on the educational material, purpose and type of lesson, they can carry out an organizing and educational role - help to form valuable skills of regulated work, ability to adhere to the established order and rhythm. At the same time, the writing itself requires a lot of stress and concentration. It is important to do dictations in a practical lesson as a 
complex exercise, because the writing of dictations is conditioned not only by the possession of writing techniques, listening skills, but also by the ability to find and determine the mechanism of connecting words in the statements.

\section{References:}

1. Neuner G. (1992). Methoden des fremdsprachlichen Deutschunterrichts / G. Neuner. Kassel: Universität Gesamthochschule Kassel, 16 p.

2. Middleman D. (1998). We listen - we speak correctly. Exercises on German pronunciation. Kyiv: Metodika, $112 \mathrm{p}$. 